\title{
PENGARUH MOTIVASI DAN PENGEMBANGAN KARIR TERHADAP KEPUASAN KERJA KARYAWAN DI PT ALAMJAYA WIRASENTOSA DEPO PEMATANGSIANTAR
}

\author{
Oleh: \\ Defi Mariani Hutabarat \\ S1 Manajemen \\ Darwin Lie, Marisi Butarbutar, Sisca
}

Abstraksi

Adapun rumusan masalah penelitian ini adalah bagaimana untuk mengetahui pengaruh motivasi dan pengembangan karir terhadap kepuasan kerja karyawan di PT Alamjaya Wirasentosa Depo Pematangsiantar. Metode penelitian yang digunakan dalam penulisan ini adalah penelitian kepustakaan dan penelitian lapangan. Populasi pada penelitian ini adalah karyawan PT Alamjaya Wirasentosa Depo Pematangsiantar yang berjumlah 24 orang. Dalam penelitian ini menggunakan data kualitatif dan data kuantitatif, dan teknik pengumpulan data dengan cara kuesioner, wawancara dan dokumentasi. Kemudian teknik analisa data menggunakan metode deskriptif kualitatif dan metode deskriptif kuantitatif.

Hasil analisa dari regresi linier berganda yaitu $\hat{Y}=16,518+0,402 \mathrm{X}_{1}+1,011 \mathrm{X}_{2}$, artinya terdapat pengaruh yang positif antara motivasi dan pengembangan karir terhadap kepuasan kerja karyawan. Kekuatan hubungan ketiga variabel adalah sangat kuat, yaitu $r=0,848$. Dari koefisien determinasi dapat dijelaskan tinggi rendahnya kepuasan kerja karyawan $71,9 \%$ dan sisanya $28,1 \%$ dijelaskan oleh faktor lainnya yang yang tidak dibahas dalam penelitian ini. Dari hasil pengolahan dan perhitungan kuesioner, penulis mendapatkan kesimpulan bahwa motivasi dan pengembangan karir berpengaruh positif dan signifikan terhadap kepuasan kerja karyawan di PT Alamjaya Wirasentosa Depo Pematangsiantar. Hal ini dibuktikan melalui uji hipotesis secara simultan, dimana hasil uji $\mathrm{f}_{\text {hitung }}(26,888)>\mathrm{f}_{\text {tabel }}(3,47)$ dengan taraf signifikansi $0,000<$ alpha 0,05 .

Kata Kunci: Motivasi, Pengembangan Karir, Kepuasan Kerja Karyawan

\section{Abstraction}

As for this research problem formula is how To determine the influence of motivation and career development on employee job satisfaction in PT Alamjaya Wirasentosa Depo Pematangsiantar. Research Method used in this writing is library research and field research. The population in this research is the employee of PT Alamjaya Wirasentosa Depo Pematangsiantar which are 24 employees. The Data used is data by qualitative and quantitative, and technique of data collecting by questionnaires, interview and documentation. Then technique analyse the data use the descriptive method qualitative and quantitative descriptive method.

Result of analysis from linear regresi modestly that is $\hat{\mathrm{Y}}=16,518+0,402 \mathrm{X}_{1}+1,011 \mathrm{X}_{2}$ meaning there are positive influence between motivation and career development on employee job satisfaction. The strength of relationship between the variables is very strength, that is $r=0,843$. From coefficient determinasi can explainable high and low of customer's purchase decision 71,9\%, and the rest $28,1 \%$ explained by other factor which is not discussed in this research. From result of processing and calculation questionnaires, writer get the conclusion that motivation and career development have positive and significant impact on employee job satisfaction in PT Alamjaya Wirasentosa Depo Pematangsiantar. This matter is proved by hypothesis test either simultaneously where result test the $f_{\text {hitung }}(26,888)>t_{\text {tabel }}(3,47)$ and which significant $0,000<$ alpha 0,05 .

Keywords: Motivation, Career Development and Employee Job Satisfaction

\section{A. PENDAhuluan}

\section{Latar Belakang Masalah}

PT Alamjaya Wirasentosa Depo Pematangsiantar adalah salah satu perusahaan distributor untuk produk PT Indofood. Produkproduk yang didistribusikan oleh PT Alamjaya Wirasentosa yaitu indomie, popmie, snack, ladaku, garam, gula, biort ultra, margarin dan bimoli. PT Alamjaya Wirasentosa Depo Pematangsiantar sebagai perusahaan distributor perlu memperhatikan berbagai faktor yang dapat meningkatkan kepuasan kerja karyawan, yaitu motivasi dan pengembangan karir. Faktor tersebut dapat dijadikan sebagai salah satu upaya untuk mencapai kepuasan kerja karyawan yang ada di perusahaan.

Kepuasan kerja merupakan salah satu faktor yang sangat penting dalam mendapatkan hasil kerja yang optimal, karena kepuasan kerja menyangkut kondisi perasaan dan emosi seseorang terhadap pekerjaan dan segala sesuatu di lingkungan pekerjaannya. Seseorang yang merasa puas dalam bekerja akan bekerja dengan baik serta membantu pimpinan dalam mencapai tujuan perusahaan. Adapun fenomena kepuasan kerja karyawan di PT Alamjaya Wirasentosa Depo Pematangsiantar digambarkan sebagai berikut: 
Tabel 1

Fenomena Kepuasan Kerja Karyawan

\begin{tabular}{|c|c|c|c|c|c|c|}
\hline $\begin{array}{c}\text { Dimensi } \\
\text { Kepuasan }\end{array}$ & SB & B & CB & TB & STB & $\begin{array}{c}\text { Juml } \\
\text { ah }\end{array}$ \\
\hline Gaji & $10 \%$ & $80 \%$ & $10 \%$ & 0 & 0 & $100 \%$ \\
\hline $\begin{array}{c}\text { Pekerjaan } \\
\text { itu Sendiri }\end{array}$ & $5 \%$ & $65 \%$ & $30 \%$ & 0 & 0 & $100 \%$ \\
\hline Promosi & $20 \%$ & $50 \%$ & $20 \%$ & $10 \%$ & 0 & $100 \%$ \\
\hline Pengawasan & $25 \%$ & $50 \%$ & $15 \%$ & $10 \%$ & 0 & $100 \%$ \\
\hline $\begin{array}{c}\text { Rekan } \\
\text { Kerja }\end{array}$ & $25 \%$ & $50 \%$ & $15 \%$ & $10 \%$ & 0 & $100 \%$ \\
\hline $\begin{array}{c}\text { Kondisi } \\
\text { Kerja }\end{array}$ & $5 \%$ & $65 \%$ & $30 \%$ & 0 & 0 & $100 \%$ \\
\hline Rata-rata & $\mathbf{1 5 \%}$ & $\mathbf{6 0 \%}$ & $\mathbf{2 0} \%$ & $\mathbf{5 \%}$ & $\mathbf{0}$ & $\mathbf{1 0 0} \%$ \\
\hline
\end{tabular}

Sumber: hasil wawancara dengan Karyawan di PT Alamjaya Wirasentosa Depo Pematangsiantar, 2017.

Pada tabel 1 di atas dapat dilihat, fenomena kepuasan kerja karyawan di PT Alamjaya Wirasentosa Depo Pematangsiantar terjadi pada dimensi promosi, pengawasan dan rekan kerja. Hal ini terjadi karena promosi yang dilakukan perusahaan yang belum sesuai dengan harapan karyawan, pengawasan dari pimpinan perusahaan begitu ketat sehingga karyawan menjadi tidak nyaman dalam bekerja dan kurang efektifnya komunikasi di tempat kerja juga menyebabkan hubungan dengan rekan kerja tidak dapat berjalan harmonis. Sedangkan pada dimensi gaji, pekerjaan itu sendiri dan kondisi kerja sudah cukup baik. Hal itu terlihat dari sistem penggajian yang merata dan tepat waktu sesuai dengan jabatannya serta memiliki fasilitas yang lengkap.

Motivasi merupakan unsur yang mendorong karyawan dalam melakukan pekerjaannya. Karyawan yang memiliki motivasi yang tinggi akan memiliki keinginan yang lebih besar untuk meningkatkan kemampuannya agar dapat melaksanakan pekerjaan dengan baik. Pemberian motivasi tidak lepas dari peran seorang pimpinan. Dalam memberikan motivasi kepada karyawan, pimpinan PT Alamjaya Wirasentosa Depo Pematangsiantar memenuhi kebutuhan akan prestasi dengan memberikan kebebasan bagi karyawannya untuk mengembangkan keterampilannya agar dapat meningkatkan prestasi kerja. Untuk memenuhi kebutuhan akan afiliasi, pimpinan menyediakan waktu untuk membantu bawahan dalam menyelesaikan permasalahan pekerjaan dan untuk memenuhi kebutuhan akan kekuasaan, pimpinan memberikan kesempatan promosi agar mendorong semangat kerja karyawan. Fenomena motivasi karyawan PT Alamjaya Wirasentosa Depo Pematangsiantar yang belum optimal terjadi pada dimensi kebutuhan akan afiliasi dan kebutuhan akan kekuasaan. Hal ini terlihat dari hubungan kerja antara pimpinan dengan bawahan dan rekan kerja yang kurang baik serta kegiatan promosi yang dilakukan perusahaan belum sesuai dengan harapan karyawan.
Selain motivasi, pengembangan karir juga faktor yang penting diperhatikan untuk mendorong kepuasan kerja karyawan. Pengembangan karir merupakan cara perusahaan untuk meningkatkan kualitas sumber daya manusia serta berperan penting dalam menghargai setiap prestasi karyawan. Pengembangan karir yang dilakukan PT Alamjaya Wirasentosa Depo Pematangsiantar dapat dilihat dari beberapa faktor yaitu sikap atasan dan rekan kerja, pengalaman, pendidikan serta prestasi karyawan. Sikap atasan dan rekan kerja, dimana karyawan meningkatkan prestasi dengan bertingkah laku yang baik, pengalaman, dimana perusahaan memberikan kesempatan pengembangan karir kepada karyawan berdasarkan masa kerjanya, pendidikan juga diperlukan untuk mendapatkan jabatan yang diharapkan, sedangkan prestasi digunakan sebagai standar untuk menduduki jabatan tertentu.

Fenomena pengembangan karir di PT Alamjaya Wirasentosa Depo Pematangsiatar terjadi pada dimensi sikap atasan dan rekan kerja. Hal ini ditunjukkan dari sikap kurangnya keterbukaan antara satu anggota dengan anggota lainnya yang dapat menimbulkan kesalah pahaman dan hubungan antar pimpinan dengan karyawan dan antar karyawan dengan karyawan menjadi kurang baik .

Pemberian motivasi dan pengembangan karir dilakukan oleh PT Alamjaya Wirasentosa Depo Pematangsianta untuk meningkatkan kepuasan kerja karyawan yang pada akhirnya dapat mendorong karyawan agar dapat menghasilkan kinerja yang lebih baik kedepannya.

\section{Rumusan Masalah}

a. Bagaimana gambaran motivasi, pengembangan karir dan kepuasan kerja karyawan di PT Alamjaya Wirasentosa Depo Pematangsiantar.

b. Bagaimana pengaruh motivasi dan pengembangan karir terhadap kepuasan kerja karyawan di PT Alamjaya Wirasentosa Depo Pematangsiantar baik secara simultan maupun parsial.

\section{Tujuan Penelitian}

a. Untuk mengetahui gambaran motivasi, pengembangan karir dan kepuasan kerja karyawan di PT Alamjaya Wirasentosa Depo Pematangsiantar.

b. Untuk mengetahui pengaruh motivasi dan pengembangan karir terhadap kepuasan kerja karyawan di PT Alamjaya Wirasentosa Depo Pematangsiantar baik secara simultan maupun parsial.

\section{Metode Penelitian}

Lokasi atau tempat penelitian ini dilakukan dPT Alamjaya Wirasentosa Depo Pematangsiantar, yang terletak di jalan Haji Ulakma Sinaga No. 109, Kelurahan Rambung Merah, Kecamatan Siantar, Telp. 085371188648, Web: http://www.alamjaya.co.id, Rambung Merah-21151. Pada penelitian ini yang menjadi Populasi dalam 
penelitian ini adalah semua karyawan PT Alamjaya Wirasentosa Depo Pematangsiantar yang berjumlah 24 orang.

Adapun Desain penelitian yang digunakan dalam penulisan skripsi ini adalah Penelitian Kepustakaan (Library Research) dan Penelitian Lapangan (Field Research). Teknik pengumpulan data yang dilakukan penulis dalam penelitian ini adalah berupa Kuesioner, Wawancara dan Dokumentasi. Adapun jenis data yang digunakan dalam penelitian ini adalah jenis data kualitatif dan data kuantitatif. Hasil data yang diperoleh dari lapangan akan dianalisis secara deskriptif baik bersifat kualitatif dan kuantitatif.

\section{B. LANDASAN TEORI}

1. Manajemen dan Manajemen Sumber Daya Manusia

\section{a. Pengertian Manajemen}

Menurut Daft (2002:8), manajemen adalah pencapaian sasaran-sasaran organisasi dengan cara yang efektif dan efisien melalui perencanaan, pengorganisasian, kepemimpinan dan pengendalian sumber daya organisasi. Menurut Handoko (2003:8), manajemen adalah proses perencanaan, pengorganisasian, pengarahan dan pengawasan usaha-usaha para anggota organisasi dan penggunaan sumber daya organisasi lainnya agar mencapai tujuan organisasi yang telah ditetapkan. Menurut Griffin (2004:8), manajemen adalah suatu rangkaian aktivitas (termasuk perencanaan pengambilan keputusan, pengorganisasian, kepemimpinan dan pengendalian) yang diarahkan pada sumber-sumber daya organisasi (manusia, finansial, fisik dan informasi) untuk mencapai tujuan organisasi dengan cara yang efektif dan efisien.

Berdasarkan pengertian para ahli di atas, maka penulis mengambil kesimpulan bahwa manajemen adalah kegiatan yang dilakukan suatu organisasi yang terdiri dari perencanaan, pengorganisasian, kepemimpinan dan pengendalian yang diarahkan kepada sumber daya yang ada dalam organisasi guna mencapai tujuan.

\section{b. Pengertian Manajemen Sumber Daya} Manusia

Menurut Dessler (2003:5), manajemen sumber daya manusia manusia adalah proses memperoleh, melatih, menilai dan memberikan kompensasi kepada karyawan, memerhatikan hubungan kerja, kesehatan, keamanan dan masalah keadilan. Menurut Rivai (20015:4), manajemen sumber daya manusia merupakan salah satu bidang dari manajemen umum yang meliputi segi-segi perancanaan, pengorganisasian, pelaksanaan dan pengendalian. Sementara menurut Mondy (2008:4), manajemen sumber daya manusia adalah pemanfaatan sejumlah individu untuk mencapai tujuan-tujuan organisasi.

Berdasarkan pengertian diatas, maka dapat disimpulkan bahwa manajemen sumber daya manusia adalah proses yang dilakukan perusahaan untuk memberikan pelatihan, penilaian dan memenuhi kebutuhan individu mulai dari pemberian kompensasi, kesehatan, keamanan serta keadilanselama dia bekerja guna mencapai tujuan organisasi.

\section{c. Fungsi Manajemen Sumber Daya} Manusia

Beberapa fungsi manajemen sumber daya manusia menurut Dessler (2003:4), sebagai berikut :

1) Perencanaan

Yaitu menentukan sasaran dan standar-standar, membuat aturan dan prosedur, menyusun rencana-rencana dan membuat pemikiran.

2) Pengorganisasian

Yaitu memberikan tugas spesifik pada setiap bawahan, membuat divisi-divisi, mendelegasikan wewenang kepada bawahan, membuat jalur wewenang dan komunikasi, mengkoordinasikan pekerjaan bawahan.

3) Penyusunan staf

Yaitu menentukan tipe orang yang harus dipekerjakan, merekrut calon karyawan, menetapkan standar prestasi, memberikan konseling kepada karyawan, melatih dan mengembangkan karyawan.

4) Kepemimpinan

Yaitu mendorong orang lain menyelesaikan pekerjaan, mempertahankan semangat kerja dan memotivasi karyawan.

5) Pengendalian

Yaitu menetapkan standar seperti kuota penjualan, standar kualitas atau tingkat produksi, memeriksa atau melihat bagaimana prestasi yang dicapai dibandingkan dengan standarstandar ini melakukan kolerasi jika dibutuhkan.

Adapun menurut Rivai (2015:13), fungsi manajemen sumber daya manusia dibagi menjadi dua, yaitu :

1) Fungsi manajerial

a) Perencanaan

b) Pengorganisasian

c) Pengarahan

d) Pengendalian

2) Fungsi Operasional

a) Pengadaan Tenaga Kerja (SDM)

b) Pengembangan

c) Kompensasi

d) Pengintegrasian

Sedangkan menurut Mondy (2008:5), fungsi manajemen sumber daya manusia ada lima, yaitu :

1) Penyediaan staf

2) Pengembangan sumber daya manusia

3) Kompensasi

4) Kesehatan dan keselamatan

5) Hubungan kekaryawanan dan perburuhan

Dari uraian diatas maka dapat disimpulkan bahwa fungsi manajemen sumber daya manusia terdiri dari perencanaan, pengorganisasian, pengarahan, pengendalian, pengadaan, pengembangan, kompensasi, kesehatan dan keselamatan karyawan, serta pengintegrasian sehingga karyawan termotivasi untuk mencapai tujuan perusahaan. 


\section{Motivasi}

Menurut Mangkunegara (2013:93), motif merupakan suatu dorongan kebutuhan dalam diri pegawai yang perlu dipenuhi agar pegawai tersebut dapat menyesuaikan diri terhadap lingkungannya, sedangkan motivasi adalah kondisi yang menggerakkan pegawai agar mampu mencapai tujuan dari motifnya. Sebutan lain untuk pengertian motivasi adalah sebagai energy untuk memicu seseorang untuk melakukan hal dengan baik. Mathis dan John (2006:114), motivasi adalah keinginan dalam diri seseorang yang menyebabkan orang tersebut bertindak. Sedangkan menurut Rivai (2015:607), mendefenisikan motivasi adalah serangkaian sikap dan nilai-nilai yang memengaruhi individu untuk mencapai hal yang spesifik sesuai dengan tujuan individu.

Berdasarkan pendapat para ahli di atas, penulis menyimpulkan bahwa motivasi adalah serangkaian sikap dan nilai yang dapat mendorong dan merangsang individu untuk melaksanakan pekerjaannya guna mencapai tujuan.

Menurut Menurut Robbins dan Timothy (2008:223), teori-teori motivasi dikelompokkan atas: 1) Teori Kepuasan

Teori ini berlandasakan faktor-faktor kebutuhan dan kepuasan individu yang menyebabkan bertindak serta berperilaku dengan cara tertentu. Konsep seperti ini mengarahkan perhatian pada faktor-faktor dalam diri orang yang menguatkan, membimbing, mendukung dan menghentikan perilakunya.

Penganut-penganut teori motivasi kepuasan, antara lain sebagai berikut:

a) Teori Motivasi Klasik

Teori ini berpendapat bahwa pada dasarnya manusia mau bekerja keras untuk dapat memenuhi kebutuhan fisik/biologisnya, berbentuk uang/barang dari hasil pekerjaannya.

b) Maslow Need Hierarchy Theory

Maslow mengemukakan teori motivasi yang dinamakan Maslow's Need Hierarchy Theory / A Theory of Human Motivation atau Teori Hieararki Kebutuhan dari Maslow. Hieararki kebutuhan mengikuti teori jamak yakni seseorang berperilaku/bekerja karena ada dorongan untuk memenuhi bermacam-macam kebutuhan. Adapun kebutuhan manusia tersusun dalam suatu hierarki, yaitu: kebutuhan fisik dan biologis (Physiological Needs). Kebutuhan keselamatan dan keamanan (Safety and Security Needs), kebutuhan sosial (Affiliation or Acceptance Needs or Belongingness), kebutuhan akan penghargaan atau prestasi (Esteem or Status Needs) dan aktualisasi diri.

c) Herzberg"s Two Factors Motivation Theory Teori two factors motivation menurut Herzberg, pada konsepnya orang menginginkan dua macam faktor kebutuhan, yaitu:
Pertama: kebutuhan akan kesehatan atau kebutuhan akan pemeliharaan atau maintenance factors. Maintenance factors (faktor pemeliharaan) berhubungan dengan hakikat manusia yang ingin memperoleh ketentraman dan kesehatan badaniah.

Kedua: faktor pemeliharaan menyangkut kebutuhan psikologis seseorang. kebutuhan ini meliputi serangkaian kondisi intrinsik, kepuasan pekerjaan yang apabila terdapat dalam pekerjaan akan menggerakkan tingkat motivasi yang kuat, yang dapat menghasilkan prestasi pekerjaan yang baik.Jika kondisi ini tidak ada, tidak akan menimbulkan rasa ketidakpuasaan yang berlebihan.

d) Teori $\mathrm{X}$ dan Teori $\mathrm{Y}$

McGregor adalah seoarang psikologis sosial Amerika yang memimpin suatu proyek dalam hal motivasi dan tingkah laku umum dari para anggota organisasi. Teori ini didasarkan pada asumsi bahwa manusia secara jelas dan tegas dapat dibedakan atas penganut teori $\mathrm{X}$ (teori tradisional) dan penganut teori $\mathrm{Y}$ (teori demokrat). Menurut teori $\mathrm{X}$ untuk memotivasi karyawan harus dilakukan dengan cara pengawasan yang ketat, dipaksa dan diarahkan supaya mereka mau bekerja sungguh-sungguh. Menurut teori Y untuk memotivasi karyawan hendaknya dilakukan dengan cara peningkatan partisipasi karyawan, kerjasama dan keterikatan pada keputusan.

e) McClelland's Achievement Motivation Theory Teori ini berpendapat bahwa karyawan memiliki persediaan energi potensial. Bagaimana energi dilepaskan dan digunakan tergantung pada kekuatan sorongan motivasi seseorang dan situasi serta peluang yang tersedia. Energi akan dimanfaatkan oleh karyawan karena didorong oleh: kebutuhan motif dan kebutuhan dasar yang terlibat, harapan keberhasilannya, nilai insentif yang melekat pada tujuan.

McClelland mengemukakan ada 3 hal yang dapat memotivasi seseorang yaitu:

(1) Kebutuhan akan prestasi (need for achievement) yang merupakan daya penggerak yang memotivasi semangat bekerja seseorang. Karena itu kebutuhan akan prestasi akan mendorong seseorang untuk mengembangkan kreativitas dan mengarahkan semua kemampuan serta energi yang dimilikinya demi mencapai prestasi kerja yang maksimal. Karyawan akan berantusias untuk berprestasi tinggi, asalkan kemungkinan untuk itu diberikan kesempatan.

(2) Kebutuhan akan afiliasi (need for affiliation) menjadi daya penggerak yang akan memotivasi semangat kerja seseorang. Oleh karena itu, kebutuhan akan afiliasi yang merangsang gairah bekerja karyawan karena setiap orang menginginkan hal-hal berikut: kebutuhan akan perasaan diterima oleh orang lain di 
lingkungan ia tinggal dan bekerja (sense of belonging), kebutuhan akan perasaan dihormati, karena setiap manusia merasa dirinya penting (sense of importance), kebutuhan akan perasaan maju dan tidak gagal (sense of achievement), kebutuhan akan perasaan ikut serta (sense of participation).

(3) Kebutuhan akan kekuasaan (need for power), merangsang dan memotivasi gairah kerja karyawan serta mengarahkan semua kemampuannya demi mencapai kekuasaan atau kedudukan yang terbaik.

f) Teori motivasi Claude S. George

Teori ini mengemukakan bahwa seseorang mempunyai kebutuhan yang berhubungan dengan tempat dan suasana di lingkungan ia bekerja, yaitu: upah yang adil dan layak, kesempatan untuk maju/promosi, pengakuan sebagai individu, keamanan kerja, tempat kerja yang baik, penerimaan oleh kelompok, perlakuan yang wajar, dan pengakuan atas prestasi.

g) Teori Kebutuhan Model Edward

Edward mengatakan bahwa ada 15 macam kebutuhan yang dapat mempengaruhi motivasi seseorang, yaitu sebagai berikut: Achievement, Deference, Order, Exhibition, Autonomy, Affiliation, Intraception Succorance, Dominance, Abasement, Nuturance, Change, Endurance, Hererosexuality, Aggression. Kelima belas kebutuhan ini pada ada pada setiap pribadi manusia, tetapi ada yang lebih besar pengaruhnya dan ada yang kurang mempengaruhi sehingga membentuk perilaku manusia dalam beraktivitas dan bersosialisasi.

2) Teori Motivasi Proses (Process Theory)

Teori ini pada dasarnya menjawab pertanyaan bagaimana menguatkan, mengarakan, memelihara dan menghentikan perilaku individu agar setiap individu bekerja sesuai keinginan manajer.Yang termasuk ke dalam teori motivasi proses adalah:

a) Teori Harapan (Expectancy Theory)

Teori harapan ini dikemukakan oleh Victor Vroom yang mendasarkan teorinya pada tiga konsep penting, yaitu: harapan (expectancy) adalah suatu kesempatan yang diberikan terjadi karena perilaku, nilai (valuance) adalah akibat dari perilaku tertentu yang mempunyai nilai/martabat tertentu (daya atau nilai memotivasi) bagi setiap individu tertentu, pertautan (inatrumentality) adalah persepsi dari individu bahwa hasil tingkat pertaman akan dihubungkan dengan hasil tingkat kedua.

b) Teori Keadilan (Equity Theory)

Keadilan merupakan daya penggerak yang memotivasi semangat kerja seseorang, jadi atasan harus bertindak adil terhadap sesama bawahannya. Penilaian dan pengakuan mengenai perilaku bawahan harus dilakukan secara obyektif (baik atau salah), bukan atas suka/tidak suka (like/dislike).

c) Teori Pengukuhan (Reinforcement Theory)
Teori ini berlandasarkan atas hubungan sebab dan akibat dari perilaku dengan pemberian kompensasi. teori ini terdiri dari 2 jenis, yaitu pengukuhan positif (positive reinforcement) yaitu bertambahnya frekuensi perilaku, terjadi apabila pengukuhan positif diterapkan secara bersyarat dan pengukuhan negatif (negative reinforcement) yaitu bertambahnya frekuensi perilaku, terjadi bila pengukuh negatif dihilangkan secara bersyarat. Jadi, prinsip pengukuhan selalu berhubungan dengan bertambahnya frekuensi dari tanggapan apabila diikuti oleh suatu stimulasi yang bersyarat.

\section{Pengembangan Karir}

Menurut Handoko

(2008:123), pengembangan karir adalah peringkat-peringkat pribadi yang dilakukan seseorang untuk mencapai suatu rencana karir. Menurut Mondy (2008:243), perkembangan karir adalah pendekatan formal yang digunakan organisasi untuk memastikan bahwa orang dengan kualifikasi dan pengalaman yang tepat tersedia jika dibutuhkan. Menurut Panggabean (2004:63), pengembangan karir didefinisikan sebagai semua usaha pribadi karyawan yang ditujukan untuk melaksanakan rencana karirnya melalui pendidikan, pelatihan, pencarian dan perolehan kerja, serta pengalaman kerja.

Berdasarkan penjelasan diatas, penulis dapat mengambil kesimpulan bahwa pengembangan karir adalah kegiatan yang ada dalam perusahaan untuk membantu karyawannya dalam mencapai rencana karirnya melalui pendidikan, pelatihan, pencarian dan perolehan kerja, serta pengalaman kerja.

Menurut Sutrisno (2011:166), faktor penentu pengembangan karir adalah:

1) Sikap atasan dan rekan sekerjanya

Seseorang ingin meneliti karirnya dengan baik, maka selain membenahi diri dengan meningkatkan prestasi juga perlu membackup dengan tingkah laku atau moral yang baik. Dengan bekal moral yang baik tersebut diharapkan akan menyenangkan atasan dan rekan sekerja, mereka semuanya merasa sejuk bila melihat kehadirannya.

2) Pengalaman

Pengalaman dalam konteks ini dapat berkaitan dengan tingkat golongan (senioritas) seorang karyawan, walaupun hal ini sampai sekarang diperdebatkan. Apakah seseorang yang berpengalaman sudah pasti memberikan kontribusi yang lebih besar daripada seniornya? Akan tetapi menilai bahwa dalam mempromosikan para senior bukan hanya mempertimbangkan pengalaman saja tetapi juga mempertimbangkan kemampuan dan keahlian.

3) Pendidikan

Faktor pendidikan biasanya menjadi syarat untuk duduk disebuah jabatan, contoh untuk bisa menduduki jenjang yang lebih tinggi harus mempunyai pendidikan minimal strata satu (S1). Dari kenyataan tersebut dapat dilihat bahwa 
faktor pendidikan mempengaruhi pemulusan karir seseorang.

4) Prestasi

Prestasi dapat saja terjadi dari akumulasi pengalaman, pendidikan dan lingkungankerja yang baik. Namun prestasi yang baik tentunya merupakan usaha yang kuat dari dalam diri seseorang, walaupun karena keterbatasan pendidikan, pengalaman dan dukungan rekanrekan kerja. Pengaruh prestasi kerja dalam menentukan jenjang karir akan sangat jelas terlihat standar untuk menduduki jabatan tertentu dominan berdasarkan prestasi.

5) Faktor nasib

Adanya faktor nasib yang turut mempengaruhi harus kita yakini, karena dalam kenyataanya ada yang berprestasi tetapi tidak pernah mendapatkan peluang untuk dipromosikan. Karena itu untuk mengeliminasi nasib, maka sangat tepat bila kita bersandar pada filosofi orang yahudi, yaitu ora et labora, berdoa dan bekerja. Untuk itu dalam meraih karir yang lebih baik, selain kita harus berusaha kerja keras, harus diikuti juga dengan doa agar nasib yang misteri ini menjadikan kita yang terbaik.

\section{Kepuasan Kerja Karyawan}

Menurut Menurut Siagian (2015:295), kepuasan kerja merupakan suatu cara pandang seseorang baik yang bersifat positif maupun negatif tentang pekerjaanya. Perilaku ini direfleksikan oleh moral kerja, kedisiplinan dan prestasi kerja. Menurut Rivai (2015:856), kepuasan kerja merupakan evaluasi yang menggambarkan seseorang atas perasaan sikapnya senang atau tidak senang, puas atau tidak puas dalam bekerja. Sedangkan menurut Mangkunegara (2013:117), kepuasan kerja adalah suatu perasaan yang menyokong atau tidak menyokong diri pegawai yang berhubungan dengan pekerjaannya maupun dengan kondisi dirinya.

Dari uraian diatas, penulis menyimpulkan bahwa kepuasan kerja adalah suatu gambaran perasaan yang dirasakan setiap karyawan baik yang berhubungan dengan pekerjaannya maupun kondisi dirinya yang berdampak pada rasa puas atau tidak puas dalam melaksanakan pekerjaannya.

Menurut Menurut Luthans (2006:243), kepuasan kerja meliputi beberapa faktor yaitu:

1) Pekerjaan itu sendiri

Kepuasan terhadap pekerjaan itu sendiri merupakan sumber utama kepuasan, di mana pekerjaan memberikan tugas yang menarik, kesempatan untuk belajar dan kesempatan untuk menerima tanggungjawab.

2) Gaji atau imbalan yang dirasakan adil

Gaji dipersepsikan adil jika didasarkan pada tuntutan-tuntutan pekerjaan, tingkat keterampilan individu dan standar gaji yang berlaku untuk kelompok pekerja tertentu maka akan menimbulkan kepuasan kerja.

3) Adanya kesempatan promosi

Kepuasan kerja seseorang dipengaruhi oleh adanya kemungkinan seseorang untuk maju dalam organisasi tersebut.

4) Pengawasan yang wajar

Atasan yang senantiasa memberikan perintah atau petunjuk dalam pelaksanaan kerja menyangkut cara-cara atasan dalam memperlakukan bawahannya.

5) Rekan kerja

Pada umumnya, rekan kerja atau anggota tim yang kooperatif merupakan kepuasan kerja yang paling sederhana pada karyawan secara individu.

6) Kondisi kerja

Bekerja dalam kondisi yang tidak menyenangkan akan menimbulkan keenganan untuk bekerja. Dalam hal ini, perusahaan harus memenuhi kebutuhan-kebutuhan fisik agar memuaskan karyawannya.

\section{Pengaruh Motivasi dan Pengembangan Karir terhadap Kepuasan Kerja \\ Karyawan}

Motivasi merupakan unsur yang penting dalam meningkatkan kinerja karyawan, karena motivasi dapat memberikan kepuasan kerja bagi karyawan tersebut dan karyawan yang puas dalam bekerja biasanya akan memberikan kinerja yang baik pula. Menurut Mangkunegara (2013:93), bahwa motivasi dapat pula dikatakan sebagai energi untuk membangkitkan dorongan dalam diri (drive arousal), yaitu bila mana suatu kebutuhan tidak terpuaskan maka timbul drive dan kegiatan seseorang untuk menanggapi perangsang (incentive) dalam tujuan yang diinginkan. Pencapaian tujuan akan menjadikan individu merasa puas.

Pengembangan karir juga merupakan salah satu faktor yang mempengaruhi kepuasan kerja karyawan. Menurut Rivai (2015:218), mengemukakan bahwa pengembangan karir merupakan hal yang krusial di mana manajemen dapat meningkatkan produktivitas, meningkatkan sikap karyawan terhadap pekerjaannya dan membangun kepuasan kerja yang lebih tinggi.

Dengan demikian dapat disimpulkan bahwa terdapat hubungan positif antara motivasi dan pengembangan karir terhadap kepuasan kerja karyawan. Adanya motivasi yang diterapkan oleh perusahaan dapat memberikan semangat bagi karyawan untuk meningkatkan kinerjanya. Demikian juga adanya pengembangan karir yang diterapkan perusahaandapat mendorong karyawan agar dapat menghasilkan kinerja yang lebih baik ke depannya.

\section{PEMBahasan}

\section{Analisa}

\section{a. Deskriptif Kualitatif}

Analisis deskriptif kualitatif dimaksudkan untuk mendapatkan gambaran atau deskripsi mengenai pengaruh motivasi dan pengembangan karir terhadap kepuasan kerja karyawan di PT Alamjaya Wirasentosa Depo Pematangsiantar. Sesudah pengujian data, maka langkah selanjutnya peneliti melakukan pengkajian analisis kualitatif 
sebagai gambaran fenomena dari variabel penelitian pada saat sekarang inii. Adapun penetapan kriteria nilai data-data jawaban dari responden tersebut dimasukkan ke dalam kelas-kelas interval, dimana penentuan intervalnya menggunakan rumus sebagai berikut:

$$
\begin{aligned}
& \text { Interval kelas }=\frac{\text { Nilai Tertinggi }- \text { Nilai Terendah }}{\text { (jumlah kelas interval) }} \\
& =\frac{5-1}{5} \\
& =\frac{4}{5} \\
& =0,8
\end{aligned}
$$

Dari rumus di atas, diperoleh nilai interval kelas $=$ 0,8, sehingga berlaku ketentuan kategori dengan hasil sebagai berikut:

Tabel 2

Nilai Interval dan Kategori Jawaban

Responden.

\begin{tabular}{|c|c|}
\hline Nilai Interval & Kategori \\
\hline $1,00-1,80$ & $\begin{array}{c}\text { Sangat Tidak Baik (STB) / Sangat } \\
\text { Rendah (SR) }\end{array}$ \\
\hline $1,81-2,60$ & Tidak Baik (TB) / Rendah (R) \\
\hline $2,61-3,40$ & Cukup Baik (CB) / Cukup Tinggi (CT) \\
\hline $3,41-4,20$ & Baik (B) / Tinggi (T) \\
\hline $4,21-5,00$ & Sangat Baik (SB) / Sangat Tinggi (ST) \\
\hline
\end{tabular}

Sumber: hasil pengolahan data

\section{1) Gambaran Motivasi di PT Alamjaya} Wirasentosa Depo Pematangsiantar

Motivasi adalah adalah suatu proses yang dapat mendorong dan merangsang individu untuk melaksanakan pekerjaannya guna mencapai tujuan perusahaan. Motivasi sangat penting dalam bekerja agar karyawan memiliki semangat dalam melaksanakan pekerjaannya. PT Alamjaya Wirasentosa Depo Pematangsiantar menggunakan 3 dimensi dalam memotivasi karyawannya antara lain kebutuhan akan prestasi dimana pimpinan memberikan insentif kepada karyawan sebagai penghargaan atas keberhasilannya dalam mencapai target. Untuk memenuhi kebutuhan akan afiliasi dimana pimpinan sering melakukan rotasi kerja kepada karyawan guna meningkatkan hubungan kerja diantara karyawandan untuk memenuhi kebutuhan akan kekuasaan dapat dilihat ketikapimpinan memberikan kesempatan promosi bagi karyawan yang memiliki kemampuan yang lebih baik dibandingkan karyawan lainya.

Berdasarkan hasil analisis deskriptif kualitatif mengenai motivasi yang diberikan kepada karyawan berada pada nilai rata-rata 3,71 dengan kriteria jawaban baik. Kemudian nilai rata-rata tertinggi sebesar 4,21 dengan kriteria jawaban sangat baik berada pada dimensi kebutuhan akan afiliasi dengan indikator berperan serta dalam kegiatan penting. Sedangkan nilai rata-rata terendah sebesar 3,13 dengan kriteria jawaban cukup baik berada pada dimensi kebutuhan akan afiliasi dengan indikator bantuan pimpinan dalam menyelesaikan pekerjaan.
2) Gambaran Pengembangan Karir di PT Alamjaya Wirasentosa Depo Pematangsiantar

Pengembangan karir merupakan kegiatan yang ada dalam perusahaan untuk membantu karyawannya dalam mencapai rencana karirnya melalui pendidikan, pelatihan, pencarian dan perolehan kerja, serta pengalaman kerja. Pengembangan karir di PT Alamjaya Wirasentosa Depo Pematangsiantar dipengaruhi oleh 4 dimensi berupa sikap atasan dan rekan kerja, pengalaman, pendidikan dan prestasi karyawan.

Sikap atasan dan rekan kerja dapat dilihat ketika pimpinan sering melibatkan karyawan dalam mendiskusikan hal-hal dalam penyelesaian masalah pekerjaan. Pengalaman dapat dilihat darikaryawan yang memiliki masa kerja serta pengalaman yang lebih banyak dari karyawan lainnya lebih dipertimbangkan untuk menduduki jabatan yang lebih tinggi. Pendidikan apat dilihat ketikaperusahaan tidak menjadikan pendidikan sebagai faktor utama dalam pengembangan karir karena ada faktor lain yang dinilai lebih penting dan prestasi dimanakaryawan yang menyelesaikan pekerjaan melebihi targer dan mampu bekerja sama dengan setiap elemen diperusahaan lebih dipertimbangkan dalam pengembangan karirnya.

Berdasarkan hasil analisis deskriptif kualitatif mengenai pengembangan karir berada pada nilai rata-rata 3,81 dengan kriteria jawaban baik. Nilai rata-rata tertinggi sebesar 4,29 dengan kriteria jawaban sangat baik berada pada dimensi pendidikan dengan indikator kualitas kerja. Sedangkan nilai ratarata terendah sebesar 3,38 dengan kriteria jawaban cukup baik berada pada dimensi sikap atasan atau rekan kerja dengan indikator rekan kerja membantu dalam pengembangan karir.

\section{3) Gambaran Kepuasan Kerja di PT Alamjaya} Wirasentosa Depo Pematangsiantar

Kepuasan kerja merupakan suatu gambaran perasaan yang dirasakan setiap karyawan baik yang berhubungan dengan pekerjaannya maupun kondisi dirinya yang berdampak pada rasa puas atau tidak puas dalam melaksanakan pekerjaannya. Kepuasan kerja karyawan PT Alamjaya Wirasentosa Depo Pematangsiantar dipengaruhi oleh faktor gajidapat dilihat ketika perusahaan memberikan gaji secara adil dan tepat waktu kepada karyawan. Pekerjaan itu sendiri dapat dilihat ketika pekerjaan yang dilakukan karyawan sudah sesuai dengan standar perusahaan dan sasaran yang telah ditetapkan serta memiliki perkembangan yang lebih baik dari sebelumnya.

Promosi dapat dilihat ketika perusahaan memberikan kesempatan kepada karyawan untuk menduduki jabatan yang lebih baik berdasarkan kemampuanya. Pengawasan dapat dilihat ketika pimpinan mengadakan briefing untuk mengarahkan dan memberi semangat karyawan dalam melaksanakan pekerjaannya. Rekan kerjadapat dilihat ketika karyawan membantu rekan kerja terutama ketika rekan kerja menghadapi masalah dalam mengantarkan pesanan. Kondisi kerjadapat dilihat 
ketika karyawan dapat melaksanakan pekerjaanya dengan lancar karena sarana dan prasarana yang telah disediakan perusahaan.

Berdasarkan hasil analisis deskriptif kualitatif mengenai kepuasan kerja yang diberikan kepada responden berada pada nilai rata-rata 3,70 dengan kriteria jawaban baik. Kemudian nilai rata-rata tertinggi sebesar 4,25 dengan kriteria jawabansangat baik berada pada dimensi gaji dengan indikator menerima gaji tepat waktu. Sedangkan nilai rata-rata terendah sebesar 3,08 dengan kriteria jawaban cukup baik berada pada dimensi pengawasan dengan indikator pimpinan memberikan bimbingan.

\section{b. Deskriptif Kuantitatif}

\section{1) Analisa Regresi Linear Berganda}

Fungsi dari analisis regresi adalah untuk melihat pengaruh yang terjadi di antara ketiga variabel. Selain itu analisis regresi juga berfungsi sebagai penunjuk arah hubungan yang terjadi antara variabel dependen dan variabel indenpenden. Untuk melihat apakah ada pengaruh motivasi dan pengembangan karir terhadap kepuasan kerja di PT Alamjaya Wirasentosa Depo Pematangsiantadigunakan analisis regresi linear berganda.

Tabel 3

Analisis Regresi Linier Berganda

\begin{tabular}{|l|r|r|c|}
\hline \multirow{2}{*}{ Model } & \multicolumn{2}{|c|}{$\begin{array}{c}\text { Unstandardized } \\
\text { Coefficients }\end{array}$} & $\begin{array}{c}\text { Standardized } \\
\text { Coefficients }\end{array}$ \\
\cline { 2 - 4 } & \multicolumn{1}{|c|}{ B } & \multicolumn{1}{|c|}{ Std. Error } & \multicolumn{1}{c|}{ Beta } \\
\hline 1 (Constant) & $\mathbf{1 6 . 5}$ & 6.967 & \\
& $\mathbf{1 8}$ & & \\
$\begin{array}{l}\text { Kualitas Pelayanan } \\
\text { Harga }\end{array}$ & $\mathbf{. 4 0 2}$ & .188 & .331 \\
\hline
\end{tabular}

a. Dependent Variabel: Kepuasan Kerja

Sumber: hasil pengolahan data instrumen dengan SPSS Versi 21(2017)

Berdasarkan hasil pengolahan data pada tabel 17 di atas, diperoleh model persamaan $\hat{Y}=16,518+$ $0,402 \mathrm{X}_{1}+1,011 \mathrm{X}_{2}$, artinya terdapat pengaruh yang positif antara motivasi $\left(\mathrm{X}_{1}\right)$ dan pengembangan karir $\left(\mathrm{X}_{2}\right)$ terhadap kepuasan kerja (Y) di PT Alamjaya Wirasentosa Depo Pematangsiantar.

\section{2) Korelasi dan Koefisien Determinasi}

Untuk menghitung kekuatan hubungan motivasi, pengembangan karir dan kepuasan kerja dilakukan melalui analisis korelasi dan koefisien determinasi dengan rumus sebagai berikut:

\section{Tabel 4}

Korelasi dan Koefisien Determinasi

\begin{tabular}{|l|c|r|r|r|}
\hline Model & $\mathbf{R}$ & $\begin{array}{c}\boldsymbol{R} \\
\text { Square }\end{array}$ & $\begin{array}{c}\text { Adjusted R } \\
\text { Square }\end{array}$ & $\begin{array}{c}\text { Std. Error of the } \\
\text { Estimate }\end{array}$ \\
\hline 1 & $\mathbf{. 8 4 8}^{\mathbf{a}}$ & $\mathbf{. 7 1 9}$ & .692 & 4.314 \\
\hline
\end{tabular}

a. Predictors: (Constant), Pengembangan.Karir, Motivasi

b. Dependent Variabel: Kepuasan Kerja

Sumber: hasil pengolahan data instrumen dengan SPSS Versi 21(2017)
Dari tabel 18 di atas diperoleh nilai koefisien korelasi $(r)=0,848$, yang artinya terdapat hubungan yang sangat kuat dan positif antara motivasi dan pengembangan karir dengan kepuasan kerja karyawan di PT Alamjaya Wirasentosa Depo Pematangsiantar, sesuai dengan kriteria korelasi pada tabel 5.

Kemudian diperoleh nilai koefisien determinasi $\mathrm{R}=0,719$, artinya baik tidaknya kepuasan kerja pada PT Alamjaya Wirasentosa Depo Pematangsiantar sebesar 71,9\% dapat dijelaskan oleh motivasi dan pengembangan karir, sedangkan sisanya sebesar $28,1 \%$ dipengaruhi oleh faktor lain seperti komunikasi, kompensasi, fasilitas dan sebagainya.

\section{3) Uji Hipotesis}

a) Uji Simultan (Uji F)

Uji $F$ digunakan untuk mengetahui apakah variabel bebas (motivasi dan pengembangan karir) berpengaruh terhadap variabel terikat (kepuasan kerja) secara bersama-sama atau simultan. Yaitu dilakukan untuk menentukan diterima atau ditolaknya hipotesis. Jika tingkat signifikan dibawah $5 \%$ atau $\mathrm{F}_{\text {hitung }}>\mathrm{F}_{\text {tabel maka }} \mathrm{H}_{0}$ ditolak.

Tabel 5

\begin{tabular}{|l|r|r|r|l|l|}
\hline Model & $\begin{array}{c}\text { Sum of } \\
\text { Squares }\end{array}$ & df & $\begin{array}{c}\text { Mean } \\
\text { Square }\end{array}$ & F & Sig. \\
\hline Regression & 1000.802 & 2 & 500.401 & $\mathbf{2 6 . 8 8 8}$ & $\mathbf{. 0 0 0}^{\text {b }}$ \\
Residual & 390.823 & 21 & 18.611 & & \\
Total & 1391.625 & 23 & & & \\
\hline
\end{tabular}

a. Dependent Variable: Kepuasan.Kerja

b. Predictors: (Constant), Pengembangan.Karir,Motivasi Sumber: hasil pengolahan data instrumen dengan SPSS Versi 21(2017)

Berdasarkan tabel 19 diatas diperoleh nilai $\mathrm{F}_{\text {hitung }}$ dengan $\mathrm{df}=\mathrm{n}-\mathrm{k}-1(24-2-1=21)$ sebesar 26,888 $>\mathrm{F}_{\text {tabel }}$ $(0,05 ; 2$ vs 21) sebesar 3,47 atau taraf signifikansi $0.000<$ $\alpha=0,05$, maka $\mathrm{H}_{0}$ ditolak, artinya motivasi dan pengembangan karir berpengaruh positif dan signifikan terhadap kepuasan kerja karyawan di PT Alamjaya Wirasentosa Depo Pematangsiantar.

b) Uji Parsial (Uji t)

Untuk menghasilkan suatu kesimpulan yang valid, maka harus dilakukan uji hipotesis. Pengujian ini dilakukan untuk menentukan diterima atau ditolaknya hipotesis, pengujian hipotesis dilakukan untuk mengetahui apakah variabel motivasi dan pengembangan karir yang diuji berpengaruh terhadap kepuasan kerja karyawan. Jika tingkat signifikansi dibawah 5\% atau $\mathrm{t}_{\text {hitung }}>\mathrm{t}_{\text {tabel }}$ maka $\mathrm{H}_{0}$ ditolak.

Tabel 6

Perkiraan Nilai thitung 


\begin{tabular}{|ll|c|c|}
\hline \multicolumn{1}{|c|}{ Model } & T & Sig. \\
\hline 1 (Constant) & 2,371 &, 027 \\
& Motivasi & $\mathbf{2 , 1 3 3}$ & $\mathbf{, 0 4 5}$ \\
\multicolumn{1}{|l|}{ Pengembangan Karir } & $\mathbf{3 , 8 1 4}$ & $\mathbf{, 0 0 1}$ \\
\hline
\end{tabular}

a. Dependent Variabel: Kepuasan Kerja

Sumber: hasil pengolahan data instrumen dengan SPSS versi 20.

berdasarkan tabel 20 diatas, diperoleh nilai $t_{\text {hitung }}$ pada variabel $X_{1}$ (motivasi) sebesar 2,133 $>t_{\text {tabe }}$ dengan $\mathrm{df}=\mathrm{n}-\mathrm{k}-1 \quad(24-2-1=21)$ sebesar 2,079 atau taraf signifikansi $0,045<\alpha=0,05$, maka $\mathrm{H}_{0}$ ditolak, artinya motivasi berpengaruh positif dan signifikan terhadap kepuasan kerja karyawan di PT Alamjaya Wirasentosa Depo Pematangsiantar.

Kemudian nilai $t_{\text {hitung }}$ pada variabel $\mathrm{X}_{2}$ (pengembangan karir) sebesar 3,814 $>\mathrm{t}_{\text {tabel }}$ dengan $\mathrm{df}$ $=$ n-k-1 $\quad(24-2-1=21) \quad$ sebesar 2,079atau taraf signifikansi $0,001<\alpha=0,05$, maka $\mathrm{H}_{0}$ ditolak, artinya pengembangan karir berpengaruh positif dan signifikan terhadap kepuasan kerja karyawan di PT Alamjaya Wirasentosa Depo Pematangsiantar.

\section{Evaluasi}

a. Motivasi PT Alamjaya Wirasentosa Depo Pematangsiantar

Berdasarkan hasil rekapitulasi penelitian, maka Motivasi sangat penting karena dapat mempengaruhi kinerja setiap karyawan di perusahaan. Motivasi di PT Alamjaya Wirasentosa Depo Pematangsiantar dapat dikatakan baik, hal tersebut dapat dilihat dari hasil kuesioner yang dibagikan kepada responden secara keseluruhan diperoleh nilai rata-rata 3,71 dengan kriteria jawaban baik.

Namun ada beberapa aspek yang dinilai baik tetapi masih ada yang dibawah rata-rata keseluruhan, yang pertama yaitu pada dimensi kebutuhan akan prestasi dengan indikator peluang mengembangkan keterampilan bernilai rata-rata 3,67 dengan kriteria jawaban baik. Upaya meningkatkan hal ini sebaiknya karyawan harus lebih diasah kemampuannya dalam melaksanakan pekerjaan sehingga dapat meningkatkan prestasi dalam bekerja, membangun dan meningkatkan kemampuan serta profesionalitas diri.

Pada dimensi kebutuhan akan afiliasi dengan indikator hubungan kerja antara pimpinan dan bawahan diperoleh nilai rata-rata 3,25 dengan kriteria jawaban cukup baik. Upaya mengoptimalkannya adalah pimpinan sebaiknya harus bisa menjadi sahabat karyawan yang memperhatikan bagaimana bawahan berkembang dan apa keinginan dari karyawannya. Pada indikator bantuan pimpinan dalam menyelesaikan pekerjaan dengan nilai rata-rata 3,13 dengan kriteria jawaban cukup baik. Upaya mengoptimalkannya adalah pimpinan dan bawahan sebaiknya harus saling berinteraksi sehingga ketika karyawan memiliki masalah dalam pekerjaanyapimpinan dapat memberikan solusi. Dan pada indikator kerjasama dengan tim kerja dengan nilai rata-rata 3,67 dengan kriteria jawaban baik. Upaya memperbaikinya adalah perusahaan sebaiknya meningkatkan interaksi sosial diantara karyawan sehingga ada pemahaman yang berkesinambungan terutama ketika karyawan melakukan pekerjaan secara tim.

Selanjutnya pada dimensi kebutuhan akan kekuasaan dengan indikator semangat kerja untuk memperoleh jabatan dengan nilai 3,67 dengan kriteria jawaban baik. Upaya meningkatkannya pimpinan sebaiknya memberikan motivasi berupa pemberian promosi bagi karyawan yang mempunyai kinerja yang baik sehingga mereka terpacu dalam bekerja. Pada indikator terlibat dalam proses pengambilan keputusan diperoleh nilai rata-rata 3,58 dengan kriteria jawaban baik. Upaya memperbaikinya sebaiknya karyawan harus sering dilibatkan dalam pengambilan keputusan yang dilakukan apabila itu menyangkut pekerjaan yang akan mereka lakukan. Dan pada indikator pemanfaatan iptek untuk mendapatkan jabatan diperoleh nilai rata-rata 3,21 dengan kriteria jawaban cukup baik. Upaya mengoptimalkannya adalah perusahaan sebaiknya selalu mengikuti perkembangan teknologi yang ada untuk mempermudah pekerjaan yang dilakukan.

Dalam hal ini dapat dilihat bahwa motivasi karyawan di PT Alamjaya Wirasentosa Depo Pematangsiantar sudah dikategorikan baik. Meskipun sudah dikategorikan baik, perusahaan sebaiknya tetap memberikan motivasi kepada karyawannya agar karyawan lebih terpacu dan bergairah dalam melaksanakan pekerjaannya.

\section{b. Pengembangan Karir PT Alamjaya Wirasentosa Depo Pematangsiantar}

Pengembangan karir merupakan merupakan tanggungjawab yang diberikan perusahaan kepada karyawan dalam mempersiapkan karyawan yang berkualifikasi dan pengalaman tertentu. Dengan adanya pengembangan karir diharapkan karyawan lebih bergairah dalam meningkatkan prestasi kerjanya. Pengembangan karir di PT Alamjaya Wirasentosa Depo Pematangsiantar dapat dikatakan baik, hal ini dapat dilihat dari hasil kuesioner yang dibagikan kepada responden yang secara keseluruhan diperoleh nilai rata-rata 3,81 dengan kriteria jawaban baik.

Namun ada beberapa indikator pengembangan karir di PT Alamjaya Wirasentosa Depo Pematangsiantar yang menjadi perhatian seperti pada dimensi sikap atasan atau rekan kerja dengan indikator kesempatan karir yang sama diperoleh nilai rata-rata 3,71 dengan kriteria jawaban baik. Upaya mengatasinya adalah perusahaan sebaiknya harus memberikan kesempatan yang sama untuk semua karyawan dan setiap karyawan berhak dalam pengembangan karir yang dilakukan perusahaan tanpa ada nepotisme di dalamnya. Pada indikator rekan kerja membantu dalam pengembangan karir diperoleh nilai rata-rata 3,38 dengan kriteria jawaban baik. Upaya memperbaikinya adalahrekan kerja sebaiknya berkomunikasi dengan efektif sehingga rekan kerja 
bisa saling berbagi informasi yang dapat membantu rekannya dalam pengembangan karir.

Pada dimensi pengalaman dengan indikator penyelesaian tugas secara efektif dan efisien diperoleh nilai rata-rata 3,75 dengan kriteria jawaban baik. upaya meningkatkannya perusahaan sebaiknya mampu mengarahkan karyawan agar meningkatkan kemampuan mereka selama bekerja karena akan sangat mempengaruhi dalam pelaksanaan tugas yang diberikan ke depannya. Pada indikator masa kerja diperoleh nilai rata-rata 3,42 dengan kriteria jawaban baik. Upaya memperbaikinya adalah karyawan sebaiknya meningkatkan kualitas kerja selama bekerja diperusahaan karena prestasi kerja yang dihasilkan di masa kerja yang dijalani karyawan akan mempengaruhi pengembangan karir yang diinginkan.

Pada dimensi prestasi dengan indikator kesempatan kepada karyawan berprestasi diperoleh nilai rata-rata 3,67 dengan kriteria jawaban baik. Upaya mengatasinya adalah karyawan sebaiknya meningkatkan prestasinya selama bekerja baik dari segi kecerdasan intelektual dan juga kecerdasan emosionalnya yang dapat membantu karyawan dalam pengembangan karir yang dilakukan. Pada indikator lingkungan diperlukan dalam peningkatan prestasi kerja diperoleh nilai rata-rata 3,42 dengan kriteria jawaban baik. Upaya meningkatkannya adalah perusahaan sebaiknya menciptakan lingkungan yang nyaman bagi setiap karyawan yang melaksanakan pekerjaannya dengan menciptakan interkasi antar karyawan melalui sebuah perkumpulan (arisan).

\section{c. Kepuasan Kerja PT Alamjaya Wirasentosa Depo Pematangsiantar}

Kepuasan kerja merupakan perasaan yang dirasakan karyawan dalam melaksanakan pekerjaannya. Semakin tinggi tingkat kepuasan karyawan semakin baik pula untuk kemajuan perusahaan. Indikator kepuasan kerja karyawan di PT Alamjaya Wirasentosa Depo Pematangsiantar sudah dalam kategori baik. Hal ini dapat dilihat dari jawaban responden dengan nilai rata-rata keseluruhan sebesar 3,70 dengan kriteria jawaban baik.

Namun tentunya ada beberapa indikator yang perlu diperhatikan karena nilainya masih di bawah nilai rata-rata keseluruhan, seperti pada dimensi gaji untuk indikator kompensasi atas kinerja diperoleh nilai rata-rata 3,54 dengan kriteria jawaban baik. Upaya meningkatkannya perusahaan sebaiknya memberikan kompesasi yang lebih baik kepada karyawan karena kompensasi dapat merangsang semangat kerja karyawan sehingga karyawan dapat memberikan kinerja terbaiknya untuk perusahaan yang berdampak pada kepuasan kerja.

Pada dimensi promosi dengan indikator jaminan jenjang karir diperoleh dengan nilai rata-rata 3,21 dengan kriteria jawaban cukup baik. Upaya mengoptimalkannya sebaiknya perusahaan memberikan jalur karir yang jelas kepada setiap karyawan untuk mengembangkan karir di
perusahaan.Pada dimensi pengawasan dengan indikator pimpinan memberikan bimbingan dengan nilai rata-rata 3,08 dengan kriteria jawaban cukup baik. Upaya mengoptimalkannya pimpinan sebaiknya memahami kebutuhan dan masalah yang dihadapi karyawan agar bisa dibimbing ke arah yang lebih baik.

Pada dimensi rekan kerja dengan indikator hubungan dengan rekan kerja diperoleh nilai ratarata 3,33 dengan kriteria jawaban cukup baik. Upaya meningkatkannya perusahaan sebaiknya menerapkan sistem komunikasi yang terbuka dan baik, dimana dengan komunikasi yang terbuka akan tercipta kerjasama dan keselarasan bagi karyawan. Pada dimensi rekan kerja dengan indikator pencahayaan diperoleh nilai rata-rata 3,42 dengan kriteria jawaban baik. Upaya mengatasinya perusahaan sebaiknya menambah pencahayaan diruang kerja dan gudang agar karyawan yang bekerja di dalam ruangan dapat melaksanakan tugasnya secara efektif dan efisien. Pada indikator kenyamanan diperoleh nilai rata-rata 3,29 dengan kriteria jawaban cukup baik. Upaya mengoptimalkannyaperusahaan perlu menambah sarana dan prasarana di kantor dan gudang untuk meningkatkan kenyamanan karyawan seperti peralatan kantor, mesin, perabot kantor, interior, tata ruang dan pencahayaan.

\section{KESIMPULAN DAN SARAN} 1.Kesimpulan

a. Hasil analisis regresi linear berganda diperoleh nilai $\hat{Y}=16,518+0,402 X_{1}+1,011 X_{2}$, artinya terdapat pengaruh yang positif antara motivasi $\left(\mathrm{X}_{1}\right)$ dan pengembangan karir $\left(\mathrm{X}_{2}\right)$ terhadap kepuasan kerja karyawan (Y) di PT Alamjaya Wirasentosa Depo Pematangsiantar.

b. Hasil analisis koefisien korelasi diporeh nilai $r$ sebesar 0,848 yang artinya terdapat hubungan yang sangat kuat dan positif antara motivasi dan pengembangan karir dengan kepuasan kerja karyawan di PT Alamjaya Wirasentosa Depo Pematangsiantar. Kemudian diperoleh nilai koefisien determinasi $\mathrm{R}=0,719$, artinya baik tidaknya kepuasan kerja pada PT Alamjaya Wirasentosa Depo Pematangsiantar sebesar $71,9 \%$ dapat dijelaskan oleh motivasi dan pengembangan karir, sedangkan sisanya sebesar $28,1 \%$ dipengaruhi oleh faktor lain seperti komunikasi, kompensasi, fasilitas dan sebagainya.

c. Hasil pengujian hipotesis secara simultan dengan uji $\mathrm{F}$ diperoleh nilai $\mathrm{F}_{\text {hitung }}$ sebesar 26,888 $>\mathrm{F}_{\text {tabel }}(0,05 ; 2$ vs 21$)$ sebesar 3,47 atau taraf signifikansi $0.000<\alpha=0,05$, maka $\mathrm{H}_{0}$ ditolak, artinya motivasi dan pengembangan karir berpengaruh positif dan signifikan terhadap kepuasan kerja karyawan di PT Alamjaya Wirasentosa Depo Pematangsiantar.

d. Hasil pengujian hipotesis secara parsial dengan uji $t$ diperoleh nilai $t_{\text {hitung }}$ pada variabel $X_{1}$ (motivasi) sebesar 2,133 $>\mathrm{t}_{\text {tabel }}$ dengan $\mathrm{df}=\mathrm{n}-\mathrm{k}-$ $1 \quad(24-2-1=21)$ sebesar 2,079 atau taraf signifikansi $0,045<\alpha=0,05$, maka $\mathrm{H}_{0}$ ditolak, 
artinya motivasi berpengaruh positif dan signifikan terhadap kepuasan kerja karyawan di PT Alamjaya Wirasentosa Depo Pematangsiantar. Kemudian nilai $t_{\text {hitung }}$ pada variabel $\mathrm{X}_{2}$ (pengembangan karir) sebesar 3,814 $>t_{\text {tabel }}$ dengan $\mathrm{df}=\mathrm{n}-\mathrm{k}-1 \quad(24-2-1=21)$ sebesar 2,079 atau taraf signifikansi $0,001<\alpha=0,05$, maka $\mathrm{H}_{0}$ ditolak, artinya pengembangan karir berpengaruh positif dan signifikan terhadap kepuasan kerja karyawan di PT Alamjaya Wirasentosa Depo Pematangsiantar.

\section{Saran}

a. Motivasi karyawan di PT Alamjaya Wirasentosa Depo pematangsiantar belum optimal. Untuk itu pimpinan perusahan harus meningkatkan motivasi bagi para karyawan dengan cara membangun sikap kekeluargaan diantara pimpinan dan karyawan sehingga karyawan merasa nyaman dan dihargai di tempat dia bekerja serta perusahaan juga sebaiknya memberikan promosi bagi karyawan yang berprestasi.

b. Untuk meningkatkan pengembangan karir di PT Alamjaya wirasentosa Depo Pematangsiantar terutama pada indikator rekan kerja membantu dalam pengembangan karir, sebaiknya perusahaan membantu dalam menciptakan komunikasi yang efektif diantara karyawan agar saling berbagi informasi yang dapat membantu dalam pengembangan karir yang diiginkan.

c. Kepuasan kerja karyawan di PT Alamjaya Wirasentosa Depo Pematangsiantar masih perlu ditingkatkan karena masih ada indikator yang belum optimal. Untuk mengoptimalkan kepuasan kerja karyawan, pimpinan perusahaan sebaiknya memahami kebutuhan karyawan dan mengidentifikasi permasalahan yang dihadapi karyawan sehinga pimpinan dapat memberikan solusi serta bimbing dalam mengatasi permasalahan yang dihadapi karyawan.

d. Sehubungan dengan keterbatasan-keterbatasan yang ada pada penulis, penelitian ini masih terdapat kelemahan-kelemahan dan belum dapat mengungkapkan seluruh variabel yang mempengaruhi kepuasan kerja karyawan di PT Alamjaya Wirasentosa Depo Pematangsiantar. Sebagai bahan masukan penelitian selanjutnya perlu memperbanyak variabel penelitian seperti komunikasi, kompensasi, fasilitas dan variabel lain yang tidak dibahas dalam penelitian ini.

\section{E. DAFTAR PUSTAKA}

Daft, Richard L. 2002. Manajemen. Jilid 1. Edisi Kelima. Jakarta: Erlangga.

Dessler, Gary. 2003. Manajemen Sumber Daya Manusia. Jakarta: Prenhalindo.

Griffin, Ricky. 2004. Manajemen. Jilid 1, Edisi ketujuh. Jakarta: Erlangga.
Handoko, T. Hani. 2008. Manajemen Personalia dan Sumber Daya Manusia. Yogyakarta: BPFE.

2003. Manajemen. Edisi 2. Yogyakarta: BPFE.

Luthans, Fred. 2006. Perilaku Organisasi. Edisi sepuluh. Yogyakarta: Penerbit Andi.

Mangkunegara, Anwar Prabu. 2013. Manajemen Sumber Daya Manusia Perusahaan. Bandung: PT Remaja Rosda Karya.

Mathis, Robert L dan John H Jackson. 2006. Manajemen Sumber Daya Manusia, Edisi Kesepuluh. Jakarta: Salemba Empat.

Mondy, R. Wayne. 2008. Manajemen Sumber Daya Manusia. Edisi kesepuluh, Jilid 1. Jakarta: Erlangga.

Panggabean, Mutiara, S. 2004. Manajemen Sumber Daya Manusia. Bogor Selatan: Ghalia Indonesia.

Rivai, Viethzal. 2015. Manajemen Sumber Daya Manusia untuk Perusahaan, edisi ketiga. Jakarta: Raja Grafindo.

Robbins, Stephen P. \& Timothy A. Judge. 2008. Perilaku Organisasi. Jakarta: Salemba Empat.

Siagian, Sondang P. 2015. Manajemen Sumber Daya Manusia. Cetakan Ke-23. Jakarta: PT. Bumi Aksara.

Sutrisno, Edy. 2011. Manajemen Sumber Daya Manusia. Jakarta: Kencana Pernada Media Group. 